\title{
Değerler Eğitimi Program Tasarılarımın Değerlendirilmesi (Antalya Örneği)
}

\author{
An Evaluation of the Values Education Programs (Antalya Sample)
}

\section{Selçuk UYGUN*}

Özet: Değer, kişi ya da toplulukların ideal kabul ettiği var olma ya da hareket etme tarzları olarak tanımlanabilir. Eğitimin asıl amaçlarından biri değerlerin kazanımıdır. Değerler okulda genelde örtük program kapsamında verilmeye çalışılır. 2011 yılında Antalya Valiliği İl Millı̂ Eğitim Müdürlüğü, okullarda değerler eğitimiyle ilgili bir proje başlatmış ve bu proje kapsamında okulöncesi, ilköğretim ve ortaöğretime yönelik "değerler eğitimi” program kitapları hazırlamıştır. Bu kitaplar (tasarılar) ile bir örtük program konusu olarak görülen değerler eğitimi, "yazılı" veya " $a c ̧ ı k$ ” bir program olarak tasarlanmış ve uygulamaya konulmuştur. Bu araştırmada, değerler eğitimi program tasarılarının değerlendirilmesi amaçlanmıştır. Tarama modeliyle yapılan araştırmada programın dört temel öğesi (hedef, içerik, eğitim durumları, değerlendirme), incelenerek program tasarısı değerlendirilmiştir. Araştırma bulguları, değerler eğitimine yönelik hazırlanan program tasarılarının uygulanabilirliği açısından önemli ipuçları sağlayacağı için önemlidir.

Anahtar sözcükler: Değerler eğitimi, örtük program, program değerlendirme

Abstract: Values can be described as the ideal ways of existence and behavioral patterns defined by communities. One of the main purposes of education is to instill values in students. While values are transmitted, mostly, via the hidden curriculum in schools, in 2011, The Provincial Directorate of National Education under the Governors' Office of Antalya began a project on values in education at elementary and secondary levels. As a part of this project, preparation of books was proposed towards values education for elementary and secondary education levels. With these books, values education, which, previously, was seen as a part of a hidden curriculum, it was proposed as a clear and written part of the curriculum. Thus, this study aims to examine the proposed books on values education. Survey methods were used to examine the program proposals (books). Four key elements of the proposed values education program (acquisitions, content, educational situations, and measurement and evaluation) were the focus of the researcher. The results of the study are important, because they will provide valuable insights into the applicability of the proposed programs.

Keywords: Values Education, Hidden Curriculum, Program Evaluation

Türk Millî Eğitimi’nin genel amaçlarında değerlere yönelik beklentiler olmasına karşın programlarda değerlerin ne şekilde gerçekleştirileceğine ilişkin açıklık yoktur. Başka bir ifade ile değerler, okul ders programlarında doğrudan ele alınan bir konu değildir. Değerler her ne kadar resmî programların amaçlarında yer alsa da okulda bunları kazandırmak genelde örtük programlara bırakılmıştır. 1739 Sayılı Millî Eğitim Temel Kanunu’nda Türk Millı̂ Eğitimi’nin Genel

\footnotetext{
* Doç. Dr., Akdeniz Üniversitesi, Eğitim Fakültesi, Eğitim Bilimleri Bölümü, Antalya, selcukuygun@akdeniz.edu.tr Bu makale 10-11 Mayıs 2012 tarihinde Ankara'da düzenlenen I. Uluslararası Eğitim Sosyolojisi Sempozyumu'nda sunulan bildirinin yeniden gözden geçirilmiş halidir.
} 
Amaçları’ndan söz edilirken değerlere sık sık vurgu yapıldığı görülmektedir. Bu değerler, kanunda "Türk Milletinin bütün fertlerini, Türk Milletinin millî, ahlâki, insani, manevi ve kültürel değerlerini benimseyen, koruyan ve geliştiren (md. 2); beden, zihin, ahlak, ruh ve duygu baklmından dengeli ve sağllklı şekilde gelişmiş bir kişiliğe ve karaktere sahip (mad. 3) bireyler yetiştirmek” şeklinde yer almıştır (MEB, 2012).

\section{Değer Kavramı}

Değerler söz konusu olduğunda daha çok inanç ve eğilimler, normatif standartlar ve amaçlar üzerine vurgu yapılmaktadır. Ancak değer kavramının tanımına yönelik disiplin alanlarına göre farklı yaklaşımlar söz konusudur (Turan, \& Aktan, 2008, 228). Değer, felsefenin temel konularından biri olsa da sosyoloji, psikoloji gibi başka disiplinlerin de çalışma konuları içinde yer alabilmektedir.

Davranış bilimciler ve sosyal psikologlar değerlerin bir yandan bireysel tutum ve davranışları, bilişsel süreçleri etkilediğini diğer yandan toplumun kültürel kalıplarıyla etkileşimde bulunduğunu ve onları yansıttığını kabul etmektedir (Dilmaç, 2002, 1). Doğan'a (2011, 327334) göre değer kavramı, bir kişi ya da bir topluluğun ideal kabul ettiği var olma ya da hareket etme tarzıdır. Değerler, gerçekleşmesi mümkün olmayan zamanlarda bile varlıklarını sürdürmeye, ya da başka bir deyişle insanlar tarafından benimsenmeye devam ederler. Güngör'e $(1993,25)$ göre değer, bir şeyin arzu edilebilir veya edilmez olduğu hakkındaki inançtır. Ancak bir değer bir tek inanca değil, bir arada organize olmuş bir grup inanca tekabül eder.

Değerler, bireyin düşünce, tutum ve yapıtlarında birer ölçüt olarak ortaya çıkar ve sosyal yapının ayrışmaz bir öğesini oluşturur. Bir toplumun hayatında, her şey değerlere göre algılanır ve diğerleriyle karşılaştırılır. Bireyler, içinde yaşadıkları grup, toplum ve kültür değerlerini genellikle benimseyerek bunları muhakeme ve seçimlerinde birer ölçüt olarak kullanırlar. Böylece daha iyi, daha doğru, daha uygun, daha güzel, daha önemli ve daha adil gibi genel yargılara varma olanağı bulurlar (Dilmaç, et alii, 2008, 70). Bu bağlamda değerlere yönelik yargıların oluşmasında etki alanı geniş olmakla birlikte okul eğitiminin rolü önemlidir. Bizatihi okulun kendisi, değerler üzerine inşa edilmiş bir yaşama ve öğrenme alanıdır (Turan, \& Aktan, 2008, 230).

\section{Değerler Eğitimi}

Çağlayan’a (2005, 91-92) göre değerler eğitimi, eğitimin vazgeçilmez amaçlarından biridir. İnsanın önemini öne çıkaran, bireysel kimliğine yeni kazanımlar kazandırarak kurumsal kimliğe anlam kazandıran bu eğitim, uzun soluklu planlamaların yapılması ile uygulamaya sokulmalıdır. Değerler eğitimi ile varılmak istenen hedef; karakterli, ahlâklı, kişilik sahibi dürüst bireyler yetiştirmektir.

Değerlerin öğrenilmesi, daha ziyade rol öğrenmesi şeklinde bir sosyal öğrenmedir (Güngör, 1993, 50). Aydın’a (2010, 4) göre değerler öğretilebilir ve öğrenilebilen olgulardır. Hayat boyu bireyin çabaları ve çevrenin etkisiyle oluşan değer eğitimi, ailede başlar, okul ile devam eder. Eğitimle ilişkisi bakımından ele alındığında değerler, hayatla doğrudan ilgili olması ve insanın insanca yaşama çabasına yardımcı olması bakımından her çağda eğitimin hem amacı hem de konusu olmuştur. Bu eğitimin nasıl yapılacağına ilişkin farklı yaklaşımlar da ortaya çıkmıştır.

\section{Değerler Eğitimi Yaklaşımları}

Kirschenbaum (1995)'a göre değerler eğitiminde değer gerçekleştirme, karakter eğitimi, vatandaşlık eğitimi, ahlak eğitimi olmak üzere dört önemli hareket ortaya çıkmıştır (akt: Akbaş, 2008, 10). Değer anlayışı ve bu anlayışa uygun olarak değerler eğitimi yaklaşımları çeşitlidir. En eski ve klasik yöntemlerden biri telkine dayalı değer öğretimidir. 
Değer ve ahlak eğitimi, İkinci Dünya Savaşı sonrası geleneksel yöntemlerle devam etmiştir. 1960 ortalarında ABD'de Sidney, Simon ve arkadaşları tarafından geliştirilen değer açıklama yaklaşımı, 1970’lerin başında Kohlberg ve arkadaşları tarafından geliştirilen ve uygulanan adil topluluk okulları gibi yaklaşımlar ile telkine dayalı değer öğretimine alternatif öğretim yolları geliştirilmiştir. Son yıllarda Türkiye'de bireyin kendi duygu, inanç, öncelik ve değerlerinin farkında olmasını ve ahlakî gelişimlerini desteklemeyi amaçlayan yaklaşımlar ise, yeni ilköğretim programlarında yer bulmaya başlamıştır. Bu tespiti yapan Akbaş'a (2008, 11-23) göre, değer eğitiminde 7 tür yaklaşımdan söz edilebilir. Bunlar; değer gerçekleştirme, değer açıklama, değer analizi, ahlakî muhakeme, karakter eğitimi, vatandaşlık eğitimi, ahlakî eğitim şeklinde sıralanabilir.

Akbaş'ın (2008, 23) değerlendirmelerine göre değer gerçekleştirme yaklaşımında bireyin kendi duygu, inanç ve önceliklerinin farkına varması, onurlu, eleştirel ve yaratıcı düşünmesi, iletişim ve sosyal becerilerinin geliştirilmesi önemsenirken, karakter eğitimi yaklaşımında bireyin kendine, çevreye ve mülkiyete saygı göstermesi, sorumlu, dürüst, güvenilir, şefkatli, kibar, yardımsever, disiplinli, azimli, tutumlu, sadık, cesur, ve iş ahlâkına sahip olması önemsenir. Vatandaşlık eğitimi yaklaşımında ise, ülkenin tarihini, kültürel mirasını, rejimini, ve demokratik sistemi anlamak, vatandaşlık hak ve sorumluklarını bilmek, anlaşmazlıkları çözme, işbirliği ve iletişim becerisi kazanma ve eleştirel düşünebilme gibi değerlere öncelik verilir. Ahlak eğitimi yaklaşımında da, ahlakî gelenek, adalet, iyi ve doğrunun anlaşılması, sevilmesi, yüksek seviyeli muhakeme, şefkat ve fedakârlık, diğerlerini düşünmek, özverili olmak, kendini kontrol, alçak gönüllülük ve ahlakî alışkanlık kazanma gibi değer ve uygulamalar programın temeli kabul edilir. Ahlak ve karakter eğitiminde bireyin ahlakî muhakeme yapması veya değerleri üzerine düşünmesi yerine toplumsal hayatın devamı için elzem olan saygı, sorumluluk, güvenirlik, adil olma gibi temel ahlakî davranışların doğrudan ya da dolaylı olarak öğretilmesi ve ahlak kazandırılması zorunlu görülmektedir. Ahlakî muhakeme, değer açılama ve değer analizi yaklaşımlarında ise bireylerin değerleri üzerine düşünmesi, değerlerin toplumsal hayattaki işlevlerini fark etmesi kısaca bilişsel süreçleri kullanması gerekir.

Hayat boyu devam eden değerler eğitiminde, okullarda değerlerin eğitim ve öğretimi daha planlı ve daha programlı yapılması gerekmektedir. Okul eğitiminin temel dayanaklarından birisi ve en önemlisi resmî okul programlarıdır. Yüksel'e (2004, 100-101) göre okulda öğrenciler, değerlerin ancak pek azını resmî programlarla öğrenirler. Aslında öğrenciler bu değerlerin büyük çoğunluğunu örtük program ile öğrenmektedirler. Ama bazen resmî programda toplum için ideal olan değerler (dürüstlük, yardımseverlik, sorumluluk sahibi olma vb.) yer almasına rağmen bazı okullarda bu değerler tam aksine öğrenme ile oluşturabilmektedir. Örneğin başarı bir değerdir. Öğrenci başarılı olabilmek için sınavda kopya çekmeyi bir fırsat olarak kullanabilmektedir. Başarı değerini öğrencisine kazandırmaya çalışan okul, bu sefer kopya çekmeyi öğretmemekle birlikte okulda oluşturduğu ortamla kopya çekmeyi teşvik etmektedir. Bu gibi nedenlerden dolayı değerlere yönelik dolaylı ve doğrudan eğitimin tespiti ve organizasyonu önemlidir. Bu da ancak program geliştirme çalışmalarıyla sağlanabilir.

\section{Değerler Eğitimi Programları}

Eğitim kurumlarında öğrencilerin düzeylerine ve ilgilerine göre değerler eğitiminin programlanması, tartışılması aklın süzgecinden geçirilmesi önemlidir (Çağlayan, 2005, 91). Değerler eğitiminin önem kazanması sonucu değerler eğitimine yönelik bazı program tasarıları da hazırlanmıştır. Türkiye’deki ilk sistemli tasarılardan biri İnsanî Değerler Eğitimi Programı’dır. Bu program John Auton tarafından İngiltere'de hazırlanıp, İstanbul'da Karşılıksız Hizmet Vakfı tarafından Türkçeleştirilen aynı isimdeki programdan yararlanarak geliştirilmiştir. Bu program 
10-14 yaş grubu çocuklar için hazırlanmış olup programa yeni oyunlar, etkinlikler, ipuçları, öykü ve şarkılar eklenmiştir (Dilmaç, 2002, 7). İnsanî Değerler Eğitimi Programı, beş evrensel değeri konu edinmiştir. Bunlar; a) sevgi, b) hakikat, c) iç huzur, d) doğru davranış, e) şiddetten kaçınma değerleridir.

Okullarımızda değerler eğitimi bazı öğretim programlanı içerisinde ve okulun örtük programı çerçevesinde yapılmaya çalışılmaktadır. Din Kültürü ve Ahlak Bilgisi, Hayat Bilgisi, Sosyal Bilgiler, Düşünce Eğitimi, Türkçe gibi öğretim programlarında ve diğer ders programlarında açık ve örtük olarak değerlerin eğitimine yer verilmektedir. Ancak değerler eğitiminin öğrenme alanlarının içerisine serpiştirilmesi ve bunun örtük programa bırakılması, değerlerin eğitim ve öğretiminin ihmaline neden olabilmektedir.

Değerler eğitimi, 18. Millî Eğitim Şurası'nda görüşülen önemli gündem maddelerinden biridir. 1739 Sayılı Millî Eğitim Temel kanunu incelendiğinde Türk Millî Eğitiminin Genel Amaçları'nda evrensel değerlerle uyumlu olarak değer eğitimine yer verilmesi gerektiği açıkça belirtilmiştir. Eğitim Bakanlı̆̆ı'nın 2010/53 genelgesiyle değerler eğitimine dikkat çekilmiştir.

Artık bazı dersler içerisinde yer alan veya örtük programla kazandırılması amaçlanan değerler açı hale getirilmekte, daha planlı ve programlı eğitim öğretim etkinliklerine yer verilmektedir. Öğrencilerin kişiliğini oluşturacak değerlerin özellikle de temel değerlerin öğrencilerde yanlış gelişmesine ailelerin ve de eğitimcilerin fırsat vermemesi için değerler eğitiminin bir program dâhilinde ele alınması kaçınılmaz olmuştur (Gelen, et alii, 2010, 238). Değerler eğitimine yönelik program çalışmalarının başlatılmasında son yıllarda izlenen eğitim politikalarının ve yönlendirmelerinin de etkisi vardır.

Bazı okullar ve il millî eğitim müdürlükleri değerler eğitimine yönelik proje ve program tasarıları geliştirmiş, böylece okullarda değerler eğitimi uygulamalarına doğrudan yer verilmesi sağlanmış oldu. Bu çerçevede Antalya İl Millî Eğitim Müdürlüğü de 2011-2012 eğitim-öğretim yılından itibaren değerler eğitimi çalışmaları başlatmıştır.

Antalya'da Değerler Eğitimi uygulamalarına ilişkin ilk çalışmalar, 2011 yılı Ocak ayında başlatılmış ve ilk çalıştay 2011 yılı Nisan ayında Antalya ilindeki 19 ilçeden seçilen koordinatörler, öğretmenler ve Akdeniz Üniversitesi, Eğitim Fakültesi'nden davet edilen öğretim üyelerinin katılımı ile gerçekleştirilmiştir. İki gün süren bu ilk çalıştayda değerler eğitimine yönelik okulöncesi, ilköğretim ve ortaöğretime yönelik üç ayrı değerler eğitimi uygulama raporu hazırlanmıştır. İl Millı̂ Eğitim Müdürlüğü çalıştayda hazırlanan bu raporlardan hareketle okulöncesi, ilköğretim ve ortaöğretime yönelik kılavuz kitaplar hazırlamış ve bunun okullarda uygulanmasını istemiştir. Bu kılavuz kitaplar bir çeşit program tasarıları şeklindedir. Bu araştırmada, bu program tasarılarını program tasarısı değerlendirme ilkelerine göre incelenmesi amaçlanmıştır. Ancak bu değerlendirme çalışmaları yapılırken, değerler eğitimi yaklaşımlarının yanı sıra okul programlarının dayandığı temel felsefî yaklaşım olan yapılandırmacılık yaklaşım da dikkate alınmıştır.

\section{Yapılandırmacı Yaklaşım}

2005 yılından itibaren yeni öğretim programlarının dayandığı temel felsefî yaklaşım, yapılandırmacılıktır. Bu yaklaşım, geleneksel program anlayışlarından köklü bir ayrışmaya işaret etmektedir. Yapılandırmacılık, bir öğretim kuramı değildir. Daha bir eğitim felsefedir. Dünyayı görme ve algılama şeklidir. Yapılandırmacılık bilginin ve öğrenmenin doğasıyla ilgili bir yaklaşımdır (Köseoğlu, et alii, 2002; Şimşek, 2004; Yurdakul, 2005). Bu felsefî yaklaşım, birden fazla "yapılandırmacı öğrenme kuramları"nın geliştirilmesine zemin hazırlamıştır. Eğitimde en çok vurgulanan yapılandırmacılık, Jean Piaget’nin "bilişsel yapılandırmacılığı” ile Lev S. 
Vygotsky’nin “sosyo-kültürel yapılandırmacıllı̆gl”dır.

Yapılandırmacı yaklaşıma göre düzenlenen program ve öğretim anlayışlarında öğrencinin bilgiyi ve anlamı kendi tecrübesine göre seçme ve anlamlandırması esastır. Bu yaklaşıma uygun öğrenme etkinliklerinde öğrenci pasif bir alıcı değil, öğrenmenin aktif katılımcısıdır. Değerler eğitimi tasarılarının da öğrencilerin değerlere dikkatini çekecek, değerler hakkında düşünmesini sağlayacak, kendi değerlerini açığa çıkaracak şekilde organize edilmesi ve bu organizasyonların program değerlendirme çalışmalarıyla geliştirilmesi kaçınılmazdır.

\section{Amaç}

$\mathrm{Bu}$ araştırmada, değerler eğitimi program tasarılarının programın öğeleri açısından değerlendirilmesi amaçlanmıştır. Bu genel amaca uygun olarak aşağıdaki sorulara cevap aranmıştır:

1) Değerler eğitimi program tasarıları hangi değer yaklaşımına göre hazırlanmıştır?

2) Değerler eğitimi etkinlikleri okul program bütünlüğüne uygun olarak yapılandırmacı yaklaşımı ne derece dikkate almıştır?

\section{Yöntem}

Bu araştırmada Antalya Valiliği İl Millî Eğitim Müdürlüğü Tarafından Okulöncesi, İlköğretim, Ortaöğretim, kurumları için yayınlanan (2011) Değerler Eğitimi Kılavuz Kitapları/Program Tasarıları doküman incelemesi yöntemine göre analiz edilmiştir. Program tasarıları programın temel öğeleri (hedefler, içerik, eğitim durumları, ölçme-değerlendirme) esas alınarak değerler eğitimine ve yapılandırmacı yaklaşımlarına göre betimsel olarak analiz edilmiştir. Bu özelliği ile araştırma, nitel bir çalışmadır.

Program değerlendirme, büyük ölçüde program geliştirme yaklaşımlarına göre farklılık gösterebilir (Erden, 1998). Bundan dolayı, tek bir program değerlendirme yaklaşımından söz edilemez. Araştırmacılar, kendi amaç ve koşullarına en uygun yaklaşımı seçebilir (seçebilirler). Ertürk'e $(1993,114)$ göre farklı program değerlendirme yaklaşımları bulunmaktadır. Bunlar program tasarısına, ortama, başarıya, erişiye, öğrenmeye ve ürüne bakarak yapılan değerlendirmelerdir. Bu çalışmada program tasarısı, programın temel öğeleri açısından yapılandırmacı öğrenme kuramı ve değerler eğitimi yaklaşımları bağlamında incelemeyi amaçlayan bir değerlendirme yöntemi izlenmiştir.

Çalışmada Parlett ve Hamilton tarafından geliştirilen bir eğitim programının tam bir resmini sunmaya çalışan, eğitim programının problemlerini ve önemli özelliklerini aydınlatmayı amaçlayan Aydınlatıcı (Illuminative) Model ile K. Sirotnik’in geliştirdiği değerlendirmenin eleştirel bir sorgulama sürecini içeren, değerlendirmenin sıkı bir öz-inceleme olduğunu ileri süren Eleştirel Sorgulama Modeli (akt: Özdemir, 2009, 138) gibi değerlendirme modelleri kullanılmıştır.

Program değerlendirme bir süreçtir (Erden, 1998, 3). Tasarlanan ve uygulanmakta olan her program değerlendirilmeye muhtaçtır. Değerler eğitimine yönelik olarak yerel anlamda tasarlanan program çalışmalarının da değerlendirilmesi önemlidir. Bu anlamda 2011 yılında Antalya Valiliği İl Millî Eğitim Müdürlüğü’nün okulöncesi, ilköğretim ve ortaöğretime yönelik hazırladığı ve uygulamaya koyduğu “değerler eğitimi” program tasarılarını değerlendiren bu araştırma, değerler eğitimine yönelik program geliştirme çalışmalarına önemli katkısı olacaktır.

\section{Bulgular}

Bulgularda değerler eğitimi program tasarısı olarak hazırlanan kılavuz kitaplar incelenmiş ve bu dokümanların önemli özellikleri aydınlatılmaya ve program geliştirme ilkeleri çerçevesinde eleştirilmeye çalışılmıştır. Program tasarısı, genel özellikler ve programın temel öğeleri açısından incelenmiştir. 


\section{A. Genel Özellikler Açısından}

Okulöncesi, ilköğretim ve ortaöğretim kılavuz kitaplarının hazırlanmasında izlenen yöntem aynıdır. Her üç tasarı, İl Millî Eğitim Müdürlügü̈’nün koordinasyonunda gerçekleşen ilgili öğretim kademelerinden seçilen öğretmen ve Akdeniz Üniversitesi Eğitim Fakültesi öğretim elemanlarından seçilen geniş bir komisyonun 2 günlük yaptığı bir çalışma sonucu hazırlanmıştır.

Çalıştay, 7-8 Nisan 2011 tarihleri arasında Antalya Turizm ve Otelcilik Lisesi'nde gerçekleştirilmiştir. Çalıştayda ilk gün “okulöncesi”, “ilköğretim” ve “ortaöğretim” alt komisyonları oluşturulmuş ve bu komisyonlar gün boyu çalışmışlardır. Çalıştayın 2. günü alt komisyonların çalışmaları, tüm katılımcıların buluştuğu genel komisyonda yine gün boyu tartışılmış ve nihai rapor İl Millî Eğitim Müdürlüğü’ne sunulmuştur. İl Millî Eğitim Müdürlüğü de bu rapordan hareketle değerler eğitimi kılavuz kitapçıklarını hazırlamıştır.

Bu hazırlık biçimiyle tasarıların bir araştırmaya dayandığını söylemek güçtür. Program tasarısı çalıştaya katılanların tecrübe ve gözlemlerine göre belirlenmiştir. Program boyutlarının oluşturulmasında 18. Millî Eğitim Şurası'nda alınan kararlar ve Bakanlığın il millî eğitim müdürlüklerine gönderdiği yönergelerin belirleyici olduğu söylenebilir. Çalıştay öncesi yapılan toplantılarda değerler eğitimine yönelik resmî yazışmalar okunmuştur.

Biçim yönünden incelendiğinde Okulöncesi değerler eğitimi tasarısı 40, İlköğretim değerler eğitimi tasarısı 56, Ortaöğretim değerler eğitimi tasarısı 72 sayfadan ibarettir. Her kitapçığın başında bu tasarıların hazırlanma amaçları şöyle açıklanmıştır:

"Bu kitapçık değerler eğitimi kurul ve komisyonlarının, kuruluş, işleyiş, görev, yetki ve sorumluluklarına ilişkin usul ve esasların tüm okullarımızda 2010/53 nolu genelgeye uygun, birlikte uygulanmasını ve işlemlerin doğru yürütülmesini sağlamak amacı ile hazırlanmıştır. Kitapçı; kurulların, komisyonların, okulların, ögretmenlerin ve ailelerin yapacakları çalışmalara ışık tutmak ve örnek teşkil etmesi için hazırlanmıştır. Kitapçıkta yer alan değerler farklı şekillerde de uygulanabileceği gibi, yapılan örnek çalışmalar değiştirilip uyarlanabilir”.

Amaca yönelik bu açıklamalardan da anlaşılacağı üzere hazırlanan tasarılar, kılavuz ve değerler eğitimi etkinliklerinin daha düzenli ve planlı bir şekilde yapılması için rehber niteliğindedir.

Değerler eğitiminin çerçevesi yalnız okulla sınırlandırılmamış; okul, aile ve çevre eğitim kapsamı içine alınmıştır.

Değerler eğitiminin daha organize ve işbirliği içinde yapılabilmesi için il ve ilçe millî eğitim müdürlüklerinde üst ve alt komisyonlar oluşturulmuş ve her komisyonun görev ve sorumlulukları tanımlanmıştır. Oluşturulan komisyonlar şunlardır: İl Yürütme Komisyonu, İlçe Komisyonu, Okul Komisyonu. Her komisyonda kimlerin görev alacağı, komisyonların görev ve sorumluluklarının neler olacağı maddeler halinde açıklandığı gibi değerler eğitiminin sürdürülmesinde yetkinliği olan okul müdürü, sınıf rehber öğretmeni, branş öğretmeni, aile ve okul aile birliği paydaşlarının da görev ve sorumlukları açık bir şekilde tanımlanmıştır. Bu sistematik yapısı ile program kitapçıkları, okul programlarının alternatifi değil, okul içinde ve okul dışında programlı eğitimin bir tamamlayıcısı olarak görülmüştür.

Okul uygulama adımlarının tanımlandığı tasarılarda sınıf içi, okul ve aileye yönelik etkinliklerin geliştirilmesi, bunların değerlendirme faaliyetleri ile izlenmesi ve faaliyet raporlarının hazırlanması çalışmaları da tanımlanmıştır. Her öğretim kademesinden hangi değerlere yer verileceği, bunların hangi örnek etkinliklerle uygulanacağı da açık bir şekilde örneklendirilmiştir. 
Tasarı kitaplarında Türk Millî Eğitimi’nin genel amaçlarına uygun olarak resmî ve açık program kaygısı taşımadan program bütünlüğü içinde değerlerin kazanımı amaçlanmıştır. Hangi değerlere öncelik verileceği konusundaki kararı bu çalışmayı yapacak komisyonlar, okullardaki değer önceliklerine göre verebileceklerdir. Bu noktada her okulun kendi aksiyon araştırmalarını yapması ve yıllık çalışma planını hazırlaması yönündeki beklentiler programı güçlendirmektedir.

Tasarılar değerler eğitimi yaklaşımları açısından değerlendirildiğinde değer gerçekleştirme, karakter eğitimi, Ahlakî muhakeme, değer açıklama ve değer analizi gibi yaklaşımların bir arada kullanıldığı görülmektedir. Değer açıklama ve değer analizi yaklaşımlarının tasarılarda daha belirgin olduğu söylenebilir. Değerlerin kazanımında sınıf içi, okul ve aile etkinlik örneklerinde; öğrencilerin kendi duygu, inanç ve önceliklerinin farkına varması, onurlu, eleştirel ve yaratıcı düşünmesi, iletişim ve sosyal becerilerini geliştirmesi, sorumlu, dürüst, güvenilir, yardımsever, disiplinli, iş ahlâkına sahip olması; değerler üzerine düşünmesi, değerlerin toplumsal hayattaki işlevlerini fark etmesi hedeflenmektedir.

Programın kazanımları, etkinlik yapıları dikkate alındığında yapılandırmacı yaklaşıma göre uyarlanmaya çalışıldığı söylenebilir. Başka bir ifade ile değerlere yönelik hazırlanan program tasarıları, 2005'ten itibaren okullarda uygulanan yeni öğretim programlarına uydurulmaya çalışılmıştır. Ancak program tasarılarında yapılandırmacı yaklaşımın ne derece ustalıkla yansıtıldığı ve değer öğretim yaklaşımlarından hangi yaklaşımının ne şekilde uygulanmak istendiği konularını açıklığa kavuşturmak için programın temel öğelerinin incelenmesi gerekmektedir.

\section{B. Programın Temel Öğeleri Açısından}

Bu kısımda değerler eğitimi tasarıları programın temel öğeleri açısından analiz edilerek eleştirel bir bakış açısı oluşturulmaya çalışılmıştır.

\section{1) A. Hedefler}

Her üç tasarı kitapta aynı olan Önsöz kısmında "evrensel değer olarak kabul gören sorumluluk, saygı, sevgi, yardımlaşma ve işbirliği, iyilik ve hoşgörü, barış ve özgüven konularında sınıf ve okul içi etkinliklerle öğrencilerimizde farkındalık oluşturulması” şeklindeki yer alan ifadeler, değerler eğitiminin amacını özetlemektedir.

Tasarılarda öğrencilere kazandırılması hedeflenen değerler, öğretim kademelerine göre şöyle belirtilmiştir:

\section{Okulöncesi kazandırılması hedeflenen değerler:}

1. Sorumluluk

4. Yardımlaşma ve İşbirliği

2. Saygi

5. İyilik ve Hoşgörü

6. Barış

7. Özgüven

3. Sevgi

\section{İlköğretimde kazandırılması hedeflenen değerler:}
1. Saygi
7. Dayanışma
13. Tutumluluk
19. Alçakgönüllülük
2. Temizlik
8. Misafirperverlik
14. Vatanseverlik
20. Onurluluk
3. Sevgi
9. Sorumluluk
15. Dürüstlük
21. Duyarlılık
4. İyilik
10. Özgüven
16. Merhamet
22. Paylaşımcılık
5. Çalışkanlık
11. Hoşgörü
17. Ahlak
6. Sabır
12. Yardımlaşma
18. Barış
23. Vefalılık
24. Cömertlik 
Ortaöğretimde kazandırılması hedeflenen değerler:

1. Saygi

2. Sorumluluk

3. Kitle İletişim Araçları
4. Kişiler Arası İlişkiler

5. Dürüstlük

6. Sevgi
7. Adalet

8. Vatanseverlik

9. Yardımlaşma ve Yardımseverlik

Öğretim kademelerinde kazandırılması gereken değerler karşılaştıııldığında okulöncesindeki değerlerin diğer eğitim kademelerinde de yer aldığı görülmektedir. İlköğretimde bu değerlere çalışkanlık, sabırlılık, dayanışma, misafirperverlik, tutumluluk, merhamet, ahlak, alçakgönüllülük, onurluluk, duyarlılık, paylaşımcılık, vefalılık, cömertlik eklenmiştir. Ortaöğretim kademesinde ise kitle iletişim araçları, kişilerarası ilişkiler, adalet değerlerine ayrıca yer verilmiştir. Bu özellik itibari ile değerler eğitimi programı sarmal bir yapıda hazırlanmıştır denilebilir. Tasarılarda yer alan değerler analiz edildiğinde amaçta yer alan değerlerin esas alındığı görülmekle birlikte bunların çok da bilinçli yapıldığını söylemek güçtür. Bu tercihler, daha çok komisyonlarda görev alanların kişisel deneyimlerine bağlı olarak ifade edilmiştir. Özelsel'e (2003, 228) göre, "değerler arasında üst düzeyde bir ahengin oluşumu, kişinin çevreye uyumunun zorunlu şartlarından biridir”. Bireylerin toplumsal uyumları ve davranışları arasında bir tutarlılığın ve sürekliliğin oluşabilmesi için değerlere yönelik ciddi ihtiyaç analizi çalışmalarına da gereksinim olduğu görülmektedir. Herhangi bir toplum yapısının analizine katkıda bulunacak en önemli unsur, o toplumun sahip olduğu değer yargılarının tespiti olacaktır (Özensel, 2003, 226).

Öğretim kademeleri bağlamında değerlere yönelik kazanımların birebir belirlenmesi ve zenginleştirilmesi, ancak öğretim kademelerine yönelik yapılacak analiz çalışmaları ile ortaya konulabilecektir. Bu yönüyle değerler eğitimi etkinlikleri ile ulaşılacak ortak kazanımların belirlenmesi aşamasında, kazanım ifadelerinin tutarlılığı, aşamalılığı vb. ilkelere dikkat edilmelidir.

Tasarı içerisinde verilen örnek etkinlik planlarında her değer için okulöncesinde "amaç", ilköğretimde "hedef davranışlar", ortaöğretimde "kazanım” kavramları altında yüzeysel de olsa bazı kazanımlara yer verilmiştir. Bütün etkinlik planlarında, genel olarak bir kazanımla yetinilmiştir. Örneğin ilköğretim tasarısında yer alan "sabır" değeri için "hedef davranış" olarak "sabır davranışı gerektiren durumları fark eder" kazanımına yer verilmiştir. Bu değerlendirmelerden de anlaşılacağı üzere kazanımların belirlenmesi ve yazımında program geliştirme yaklaşımlarına pek uyulmadığı görülmektedir.

\section{1) B. Kazanımlar}

Programlarda gerçekleştirilmesi gereken özelliklerin kavramlaştırılması programların dayandığı yaklaşımlar açısından ipuçları taşır. Örneğin "amaç" gelenekseli, "hedef davranış" davranışçılığı, "kazanım” yapılandırmacılığı çağnıştırır. "Hedef-davranış” ifadesi yerine "kazanım” ifadesinin tercih edilmesinin bir nedeni de, öğrenciyi merkeze alan bir yaklaşım olmasıdır. Öğrenci, dışarıdan bilgilerin yerleştirileceği boş bir kutu değildir. Bilişsel yapılandırmacı Piaget’ye göre, öğrencinin zihni her uyarana anlam veren ve bu anlamları bilişte dengeleyen dinamik bir yapıdır. Bu yapı; deneyimlerden, içinde bulunulan kültürden, öğrenmenin gerçekleştiği etkileşimin doğasından ve bireyin bu süreçte üstlendiği rolden etkilenmektedir (Yurdakul, 2005, 43).

Kazandırılması gereken özelliklerin ifadelendirilmesi analiz edildiğinde ortak bir yaklaşımın belirgin olmadığı görülmektedir. Örneğin tasarılarda örnek olarak verilen etkinliklerde yer alan bazı ifade biçimleri şöyledir:

"Saygı" değeri için;

Okulöncesi: “Amaç: Öğrencilerin duygularının farkındalık düzeylerini artırmalarına ve başkalarının duygularına saygı konusunda anlayış geliştirmelerine yardımcı olmak”. 
İlköğretim: “Hedef-davranışlar: Saygı kurallarını kavrar. İşbirliği yapmayı geliştirir”.

Ortaöğretim: "Kazanım: Farklı olmanın ne demek olduğunu anlarlar".

$\mathrm{Bu}$ örneklerde de görüldüğü gibi öğrenilmesi gereken özelliklerin ifadelendirilmesinde öğrenmeye dönüklük, açıklık, gözlenebilirlik, ölçülebilirlik ve uygulanabilirlik ilkelerine uygunluk boyutlarında ciddi sorun ve çelişkiler söz konusudur.

\section{2) İçerik (muhteva-kapsam)}

Tasarıların içeriği analiz edildiğinde her tasarı kitapçığında adı geçen değerlerin ne anlama geldiği kısa kısa açıklanmış ve yıllık çalışma planları oluşturulmuştur. Bu planların uygulanmasında alt değerlere, yapılacak etkinliklere ve yararlanılacak kaynak ve kişilere de yer verilmiştir. Planların uygulanmasında etkinlik örnekleri de verilmiştir. Yıllık çalışma planında değerler aylara göre paylaştırılmış ve her ay hangi değerlere yönelik nasıl bir eğitimin yapılacağı da açıkça belirtilmiştir. Her tasarı kitapçığının sonunda değerlere yönelik örnek hikâye ve yazılara da yer verilmiştir. Bunlar, değer metinleri olarak da değerlendirilebilir.

Değerlere yönelik eğitim muhtevasının belirlenmesinde tasarı kitapçıklarında yer alan değerler ve bunlara yönelik hazırlanan etkinlikler örnek olarak seçilmiştir. Bunlar; kurulların, komisyonların, okulların, öğretmenlerin ve ailelerin çalışmalarına ışık tutması ve örnek teşkil etmesi için hazırlanmıştır. Başka bir şekilde ifade edecek olursak, değerlere yönelik yapılacak eğitimin yalnız bu değerlerle sınırlandırılmadığı anlaşılmaktadır. Ancak örnek olarak seçilen bu değerlerin de hangi ölçütlere göre nasıl seçildiği konusuna bir açıklık getirilmemiştir.

Değerler dünyası, hiyerarşik bir yapı arz eder. Değerlerin küresel ve hiyerarşik yapısı özellikle sosyal değişimin açılanması ve tahmin edilmesi açısından önemlidir (Doğan, 2011, 329330). Örnek olarak seçilen değerler analiz edildiğinde daha çok evrensel niteliklere uygun olanların tercih edildiği söylenebilir.

Değerler toplumsal, ulusal ve küresel boyutta sınıflanabilir. Toplumsal değerler, bir toplumun çoğunluğu tarafından paylaşılan, toplumun iyiliğine ve esenliğine yönelik olduğu varsayılan ideal ortak paylaşım ölçütleridir. Toplumsal değerlerle ulusal değerler çatışmaz, bilakis toplumsal değerler ulusal değerlere hayatiyet verir. Tüm toplumların benimsediği değerler ise, evrensel boyuttadır. Buna küresel değerler de denilebilir. Küreselleşmenin bizatihi kendisi değişim kültürünün yeni bir değeridir (Doğan, 2011, 331). Bireylere kazandırılmak istenen toplumsal ve ulusal değerlerin küresel değerlerle bağdaştırarak öğrencilerin düzey ve ilgilerine göre programlanabilmesi için kazanımların geliştirilmesine yönelik aksiyon araştırmaları yapılmalıdır.

Değerler eğitiminde kazanımları açık ve bütünleşik şekilde yazmanın güçlükleri de vardır. Çünkü değerler, resmî programların amaçlarında yer alsa da öğrenme özellikleri bakımından örtük programın kapsamı içerisinde de kazandırılması gereken özelliklerdir ve disiplinler arasıdır. Bu bakımdan düşünüldüğünde derslere yönelik hazırlanan resmî programlar gibi bir tasarı hazırlamanın ve bu tasarıda öğrenme türlerini dikkate alan aşamalılık ilkesine dayalı kazanımlar yazmanın da güçlüğü dikkate alınarak istenmeyen öğrenmelerin en aza indirgenmesi için kazanımlar üzerinde yeni ve sürekli çalışmalar yapılmalıdır. Bu tür çalışmalar değerler eğitiminin etkinliğini artıracaktır.

Değerler ile insanlar arasındaki ilişki karşılıklıdır; değerler insanları, insanlar değerleri yaşatır. Ancak değerler sosyal kategorilere göre farklı düzeylerde algılanmaktadır (Aydın, 2003, 122). Öğrencilerin geldiği sosyal kategorilere göre değerlere yönelik algılar değişebildiği gibi, öğrencilerin düzeyleri ve ilgileri de onların algılarını farklılaştırabilmektedir. İşte bu noktada değerlere yönelik kazanımların belirlenmesi önem taşımaktadır. Tasarı kitaplarının farklı öğre- 
tim kademelerini esas alarak hazırlanması bunun dikkate alındığını göstermektedir. Ancak yeterli değildir. Okulda ve sınıfta değerlere yönelik eğitimin kazanımlara uygun gerçekleşmesinde sosyal, kültürel vb. alanlarda yapılan çalışmaların verilerinden de yararlanma yoluna gidilmelidir. Zira değerler eğitimi disiplinler arası kazandırılması gereken bir eğitim türüdür.

\section{3) Eğitim Durumları}

Değerler eğitimi program tasarı kitapçıklarının asıl hazırlanma gayelerinden biri değerler eğitimine yönelik yapılacak çalışmalara ve etkinliklere ışık tutması ve örnek teşkil etmesidir. Bu amaca uygun olarak komisyonların ne tür etkinliklerde bulunacağı açık bir şekilde tanımlanmıştır. Örneğin okul komisyonlarının tanımlanan görevlerinden bazıları maddeler halinde şöyledir:

1. İl ve ilçeden gönderilen talimatlara uygun olarak Yıllık Çalışma Planı hazırlar ve okul müdürünün onayından sonra yürütülmesini sağlar.

2. Okulda yürütülecek “Değerler Eğitimi” çalışmaları ile ilgili olarak öğretmen, öğrenci ve velileri bilgilendirir.

3. Okul içerisinde ve dışında yürütülecek çalışmaları; “Okulun tamamına yönelik Etkinlikler, Sını İçi Etkinlikler ve Aileye Yönelik Etkinlikler” olmak üzere üç ana başlıkta planlanır.

\subsection{Eğitim Ortamı}

Komisyonların bu görevlerinden de anlaşıldığı gibi, değerler eğitimi yalnız okul eğitimi ya da okul içinde bir ders eğitimi gibi düşünülmemiştir. Bu eğitim, okul içinde ve dışında planlı, düzenli ve sürekli yürütülebilecek örtük ve resmî bir eğitim programı olarak tasarlanmıştır. Özellikle örtük konuların düzenli ve planlı şekilde yapılabilmesi için hazırlanan öğretim tasarıları örnek olarak gösterilmiştir.

Tasarılarda değerler eğitiminin uygulanmasıyla ilgili öğretmenlere rehber olabilecek birçok açıllamalara ve örneklendirmelere yer verilmiştir. Bunlar okulun tamamına yönelik, sınıf içi ve aileye yönelik etkinlikler olarak içerikte yer almıştır.

Tasarıda yer alan açıklamalara göre, değerler eğitiminin ortamı yalnız okul değildir. Bu eğitim ailede, okulda, çevrede ve her yerde yapılabilecek bir eğitim olarak tasarlanmıştır. Ancak bu eğitimin sürdürülebilmesi için okul eğitiminin üzerine düşen görev ve sorumlukları bu tasarı ile açıklığa kavuşturulmuştur.

Okul müdürünün görev ve sorumluluklarında değerler eğitiminin işbirliği içinde gerçekleştirileceği ve bu koordinasyonu sağlayacak olanın da okul müdürü olduğu ifade edilmektedir. Buna ilişkin bir açıklama şöyledir: "Okulun iç (yönetici, öğretmen, öğrenci ve diğer personel) ve dış öğeleriyle (okul aile birliği, veliler, sivil toplum kuruluşları, üniversite, resmî, özel kurum ve kuruluşlar vb.) iş birliği içinde çalışır”. İşbirliğini öngören bir başka açıklama ise şöyledir: "Etkinlikler, konuların uygunluğu, ögrrencilerin yaş düzeyleri, sınıfların yapısı dikkate alınarak seçilir ve uygulanır. Gençlere birbirleriyle etkileşimde bulunabilecekleri, işbirliği yapabilecekleri aktif öğrenme ortamı sağlanır”. Bu maddede de görüldüğü gibi, değerler eğitiminde merkezde öğrencinin bulunduğu işbirliğine dayalı aktif öğrenme modeli öngörülmektedir.

\section{2 Öğretim Stratejileri, Yöntem ve Teknikleri}

Değerler eğitiminde okulun tamamına yönelik etkinliklerde "değerler eğitiminin să̆lıklı bir zeminde yürütülmesi, istenilen hedeflere daha kolay ulaşılabilmesi bakımından, okul ortamında verilmek üzere tespit edilen değerler ile çevre şartlarının çatışmaması ve verilmek istenen eğitimin uyum içerisinde yürütülmesini sağlayıcı tedbirler alınır. Bunun için çevrenin olumlu ya 
da olumsuz yargıları çok iyi tespit edilmelidir” ilkeleri ile değerlerin eğitiminde çevre şartlarının ve öğrencilerin hazırbulunuşluk düzeylerinin dikkate alınması gerektiğine vurgu yapılmıştır.

Açıklamalarda değerler eğitiminin nasıl yapılacağına ilişkin bazı yöntem, teknik ve uygulamalara da yer verilmiştir. Örneğin okul komisyonlarının görevleri arasında "değerler ĕgitimi ile ilgili topluma örnek olmuş kişileri belirler ve okula davet eder; seminer, konferans, söyleşi, gezi, kermes vb. faaliyetleri planlar ve uygular" denmektedir. Yine okulun tamamına ve aileye yönelik etkinliklerin uygulanmasında yer verilen açıklamalardan bazıları şöyledir:

- Değerlere uygun model alınabilecek kişiler tanıtılır. Değerler eğitimine katkı sağlayabilecek toplum önderlerinden ve örnek kişilerden yararlanılır.

- Kitap tanıtımları yapılır.

- Değerle ilgili kısa filmler seyrettirilir.

- Gençlerin ayın değeri ile ilgili araştırma yapmaları sağlanır.

- Ailelere yönelik eğitim çalışmaları düzenlenir.

$\mathrm{Bu}$ açıklamalardan da anlaşılacağı üzere değerler eğitiminde asıl amaç okul öğrencilerinin eğitimidir. Ancak bu eğitimi amaca uygun gerçekleştirebilmek için gerektiğinde ailelere yönelik de eğitim çalışmalarının yapılabileceği görülmektedir.

Tasarı kitapçıklarında aylara göre planlanan Yıllık Çalışma Planları’nda “alt değerler”, yapılacak etkinlikler”, “yararlanacak kaynak ve kişiler” şeklinde bazı alt başlıklara yer verilmiştir. Yapılacak etkinlikler başlığı altında bazen ne tür yöntem, teknik ve materyallerin kullanılacağı da belirtilmiştir. Ancak bunlar düzenli değildir, ama uygulamada alışkanlığa dayalı uygulamalı ya da yaparak yaşayarak öğrenme etkinliklerine dayalı yöntem ve tekniklerin kullanılacağı anlaşılmaktadır.

Öğretim kademelerine göre bakıldığında değerler eğitiminin kazandırılmasında izlenen strateji, yöntem ve tekniklerin öğrencilerin yaş düzeylerine uygun olmasına özen gösterildiği söylenebilir. J. Piaget, değerlerin çeşitli yaş devreleriyle birlikte ilerlediğini ve değer-düşünce gelişiminin paralel yürüdüğünü belirtir (akt. Aydın, 2003, 127). Bu sebeple farklı öğretim kademelerinde öğrenim gören öğrencilere değerler, farklı düzeylerde uygun yöntem ve tekniklerle kazandırılmalıdır.

Okul öncesinde hikâye yoluyla öğretim yöntemi ve etkinliklerine daha çok yer verilmesi gerektiği anlaşılmaktadır. Örneğin "Sorumluluk" değeri için sınıf içinde yapılacak bir etkinlik şöyle tasvir edilmiştir:
"Etkinlik 1: Hikâye okuma ve hikâyenin canlandırılması (Büyük Grup çalışması): Eğitici, çocuklara ă̆ustos böceği ve karıncanın masalını an- latarak masaldaki sorumluluklara dikkat çeker. Ağustos böceğinin düş- tüğ̈̈ zor durum hakkında soru-cevap yapılır. Masal paylaşıldıktan sonra çocuklar tarafindan masala uygun bir son yazılarak masal iki şekilde de dramatize edilir. Canlandırma sırasında hissettikleri ile konuşularak sorumluluklar hakkında konuşulur".

Bu etkinlikte de görüldüğü gibi öğrencinin düşünmesi, sorgulaması ve değerin açılanmasında aktif olması gerektiği anlaşılmaktadır. İlk ve ortaöğretim kademelerinde de öğrencileri merkeze alan çalışmaların etkinlik olarak tasarlandığı görülmektedir. Ancak ortaöğretimde proje ve araştırma çalışmalarının, konferans, seminer vb. yöntem ve tekniklerin de kullanılabileceği görülmektedir.

Tasarılarda yer verilen Yıllık Çalışma Planları ve diğer etkinlik örneklerinde etkinliklerin 
zenginleştirilmesi ve geliştirilmesine vurgu yapılmıştır: Örneğin Ortaöğretim için hazırlanan tasarıda Yıllık Çalışma Planları'nın sonunda "Planda gösterilen yapılacak etkinliklere ilave olarak değerlerle ilgili değişik etkinlikler okul komisyonunca belirlenir. Kitapçı̆̆ın ekinde yer alan etkinlik örnekleri uygulanabileceği gibi yeni etkinlikler de geliştirilebilir” açılamasına yer verilmiştir.

Eğitim kurumlarında uygulanan yöntemler, konulan kurallar, hazırlanan ortamlar hangi nitelikler taşırsa taşısın tüm bu öğelerin öğrencilere sevdirilmesi, benimsetilmesi, yapılanların görünebilir, yaşanabilir, uygulanabilir özellikler taşımasına önem vermek gerekir.

Tasarılarda değerler eğitimi konuları ile bunların nasıl kazandırılacağına ilişkin etkinlik ve açılamalar iç içe geçmiştir. Bu özelliği ile tasarıların Çağlayan'ın $(2005,94)$ değerler eğitimi konularının belirlenmesi ve kazandırılması yönündeki önerilerine uygun olduğu söylenebilir. Çağlayan'ın $(2005,94)$ bu konudaki bazı önerileri şöyledir:

- Değerler eğitiminin öneminin kurul ve zümre toplantılarında gündeme gelerek bu eğitimin ciddiye alınmasında yönetimin işi sahiplenmesi, öğretmenlerin bu proje ağırlıklı çalışmalara rehberlik etmesi,

- Değerler eğitiminde işlenecek, kavranacak konuların belirlenmesi,

- Komitelerin oluşturulması,

- İş takviminin belirlenmesi,

- Görevli öğretmen ve öğrencilerin seçilmesi,

- Panoların düzenlenmesi ve spot cümlelerin okulun değisşik alanlarına asılması,

- Konu ağırlıklı anı, şiir ve öykü yazımı, ilgili seminerlerin öğrenci, öğretmen ve veliye verilmesi,

- Etkinliğe zenginlik kazandıran tiyatro, oratoryo ve skeçlerin yapılması,

- Bilgisayar destekli sinevizyon gösterimi,

- Mesaj duvarları oluşturarak konu ağırlıklı sözlerin tanıtımının yapılması,

- Konu ağırlıklı yazılı eserlerin ve dergilerin tanıtılması,

- Sivil toplum örgütleri ile işbirliğinin gerçekleştirilmesi,

- Sınıfta, okulda değerler panosunun özel olarak hazırlanması,

- Rehberlik hizmetlerinin konularla ilgili öğrenci anketleri oluşturması,

- Resim, karikatür sergisinin açılması; çizgilerle konunun tanıtılması,

- Yapılan etkinliklerin değerlendirilmesi ve ödüllendirilmesi,

- Yapılan çalışmaların davranışlara olan etkisinin gözlenmesi.

Aydın (2010, 10), değerler ve ahlak eğitiminde eğitsel oyun, işbirliğine dayalı grup çalışmaları, çoklu zekâ, örnek olay incelemesi ve dramatizasyon yöntemlerinin etkili bir şekilde kullanılabileceğini ifade etmektedir. Tasarı kitapçıklarında da benzer yöntem ve tekniklerin kullanımı istenmektedir. Bu açılamalarda görüldüğü gibi, programın temel felsefesi yapılandırmacı yaklaşıma daha uygundur. Özellikle program taslağının uygulanmasıyla ilgili öğretmenlere rehber olabilecek birçok açıklamalara ve örneklendirmelere yer verilmiştir. Örneğin öğrenme stillerine göre çoklu öğrenme ortamlarının oluşturulması ve öğrenme ortamları için öğretmenin yardımcı ve yol gösterici özelliği, öğrencilerin bilgi ve beceri kazanma konusundaki sorumluluğu ve aktifliği konuları sık vurgulanmaktadır.

Değer öğretimi yaklaşımı açısından bakıldığında telkine dayalı değil de yapılandırmacı yaklaşımın felsefesine de uygun olan değer açıklama ve değer analizi yaklaşımlarının program tasarısında tercih edildiği söylenebilir. Etkinlik örnekleri, bireylerin kendi duygu, inanç ve değerlerinin farkına varması kendilerinin güçlü ve zayıf yönlerini bilmesi yönünde ve kendilerini olumlu yönde geliştirmesi şeklinde tasarlanmıştır. Yapılan etkinliklerle gönüllü olarak çocukla- 
rın bazı değerleri içselleştirerek davranış haline getirmesi tasarıların ortak hedefidir.

Aydın’a $(2010,10)$ göre, değer açıklama; sınıf oyunları, sergiler vb. etkinliklerle özel olarak seçilmiş konular sayesinde yapılır. Öğretmenler, değer açıklamasını tüm yaş seviyelerinde ve konularda kullanabilir. Bu yaklaşımı benimseyen öğretmenler, grupla çalışmaya önem verirler. Seçme esasına dayalı değer açıklama yaklaşımının aşamaları şöyle sıralanabilir:

- Özgürce seçim ya da bağımsız seçim yapma,

- Bir dizi mevcut seçeneği değerlendirdikten sonra alternatifler arasından seçebilme,

- Her alternatifin olası sonuçlarını düşünerek değerlendirdikten sonra seçebilme,

• En önemli ve değerli olduğu düşünülen şeyleri ödüllendirme ve değer verme,

- Serbestçe seçilen bir değeri açıkça söyleyebilme,

- Seçilen değerle uyumlu olan bir hareket tarzıyla (tavır) hareket edebilme,

- Seçilen değerle uyum içindeki hareket tarzını alışkanlık haline getirme.

Sıralanan değer açıklama ilkeleri esas alındığında tasarılarda seçme, ödüllendirme ve davranış aktiviteleri ile kendi yaşantıları yoluyla öğrencilerde değerleri içselleştirmeleri istenmektedir. Örneğin "sabır" değeri için uygulanması istenen etkinliğin sonunda öğretmenin yapması gerekenleri şu şekilde açıklamaktadır: "Etkinlik sonunda halka biçiminde oturulur. Sabırlı olma davranışının bu oyundaki başarıyı nasıl etkilediği konuşulur. "Sabretmemiz gereken durum ve davranışlar nelerdir?” sorusu üzerinde konuşulur.” Ancak değerlerin uygulamadaki başarısı bu beklentilerin ne derece gerçekleşip gerçekleştirilemediğini gösterecektir ve etkinliklerin icrasinda ise öğretmenin oynayacağı rol önemlidir.

Tasarıda değerlerin gerçekleştirilmesine yönelik beklentilerin gerçekleşebilmesi için genel olarak gerekli materyallerin kullanımına da işaret edilmiştir. Örneğin komisyonların görev ve sorumluluklarında "değerler eğitimi için gerekli olan yazılı ve görsel materyalleri (yerel, ulusal, uluslar arası özellikle film, fotoğraf, slayt, kitap, dergi, broşür vb) belirler” denmektedir.

\section{4) Ölçme-Değerlendirme}

Tasarılarda değerler eğitimi uygulamalarının etkililiği, daha çok sürece bakarak değerlendirilmek istenmiştir. Sürecin başarısı değerler konusunda beklentilerin gerçekleşip gerçekleşmediği ile yakından ilgilidir. İl Yürütme Komisyonu'nun görev ve sorumluluklarında, “değerler eğitimi ile ilgili; öğrenci, sınıf, okul, ilçe bazında yürütülen çalışmaları izler, rehberlik eder, değerlendirir" (madde 5), okul komisyonun görev ve sorumlukları arasında ise, "değerler eğitimi verimliliğini arttırmak, eğitimin kalitesini yükseltmek ve sürekli gelişimini sağlamak için gerekli araştırmaları yapar, iyileştirme projeleri hazırlayarak okul müdürünün onayından sonra bu projeleri uygular ve sonuçlarını değerlendirir" (madde 10) ilkelerine yer verilmiştir.

Okul komisyonlarının her dönem okulda yapılan değerler eğitimi faaliyetleri ile ilgili rapor hazırlanması gerektiğinin belirtilmesinin yanı sıra "izleme ve değerlendirme" etkinliklerine yönelik yapılan açıklamalardan bazıları şöyledir:

“Çalışma kapsamında yer alan değerlerin davranışa dönüşüp dönüşmediği, ögrencilerdeki yansımaları dikkatli ve titiz bir şekilde takip edilir. (...) Il Yürütme Kurulunca hazırlanan anketlerin, talimatlar doğrultusunda elektronik ortamda ya da matbu form olarak öğrenci-öğretmenvelilerce doldurulması sağlanır. Okula gönderilen anket sonuçlarına göre faaliyetlerini gözden geçirir ve yeniden planlar”.

Değerler eğitimi uygulamalarının etkililiği için okul, sınıf içi ve aileye yönelik etkinliklerin uygulamasına yönelik “öz değerlendirme” etkinliklerinin de yapılması ve tasarıda yer alan 
etkinliklerin sürekli geliştirilmesi, değerler eğitimi program tasarılarının amaçları arasındadır. Program tasarılarına göre değerlendirmenin öncelikli amacı; değerler eğitimi etkinlik uygulamalarının değerlendirilmesi ve bu yolla eksiklerin giderilerek daha etkili uygulamaların geliştirilmesini sağlamaya yöneliktir. Özetlenen bu ilkeler çerçevesinde programın değerlendirme yaklaşımı düşünüldüğünde "yapılandırmacı” yaklaşımın belirgin özelliklerine rastlanmaktadır. Yurdakul’a (2005, 53-54) göre yapılandırmacı değerlendirmenin bazı özellikleri şunlardır:

- Öğrenmelerin ölçülmesi yerine; nedenler ve nasıllar araştırılarak, gerçekler ve dayanaklara sunularak yapılan değerlendirmeyle de öğrenmenin gerçekleşmesidir.

- İçeriğe ulaşılıp ulaşılmadığının ölçülmesi değil; öğrenme sürecini anlamaya odaklanmalıdır.

- Öğrenenlerin birey olarak ne kazandıklarından çok; bunları nasıl kazandıklarını anlamasıdır.

- Önceden belirlenmiş, ulaşılması istenir davranışlara değil, süreç içinde oluşan kazanımlara dayalıdır; daha ayrıntılı ve bütüncüldür.

Değerler eğitiminde ölçme-değerlendirme etkinliklerinin sürece yönelik yapılması değerlerin doğasına uygundur. Çünkü değerlerin içselleştirilmesi sevgi temelinde seçme, ödüllendirme, davranış ve kendiliğinden kazanılan alışkanlıklarla gerçekleşebilir. Değerlerin ne derece kazanılıp kazanılmadığının belirlenmesinde ise anket, görüşme, gözlem vb. tekniklerin kullanılması ile bazı tespitler yapıldıktan sonra sürecin iyileştirilmesi ve geliştirilmesi öğrenmenin doğasına uygun olacaktır.

\section{Sonuç ve Genel Değerlendirme}

Değerler eğitimi, örtük ve resmî programların bütünleşmesi ile gerçekleştirilebilecek bir eğitim türüdür. Bundan dolayı değerler eğitimi program tasarılarının geliştirilmesinde yerel çalışmalar önemsenmektedir. Antalya İl Millî Eğitim Müdürlügü̈nün çalışması da bu kapsamda değerlendirilmelidir. Ancak bu tür program tasarılarının hazırlanmasında tam veya yarı zamanlı program tasarımcılarına da ihtiyaç olduğu görülmektedir.

Değerler eğitimi program tasarılarının genel eğitim programlarına uygun olarak yapılandırmacı yaklaşımın etkisi altında geliştirilmeye çalışıldığı görülmektedir. Ancak programın öğeleri açısından bakıldığında bir bütünlük ve tutarlılığın da olmadığı anlaşılmaktadır. Bu yüzden farklı uzmanların yanı sıra eğitim programcılarının da bu etkinliklerde görev alması ve yapılanları sürekli izleme ve değerlendirme çalışmaları ile katkı sağlaması gerekmektedir.

Yapılandırmacı programların temel öğrenme-öğretme yaklaşımı öğrenciye anlamı ya da bilgiyi kendi deneyimleri ile yapılandırma fırsatı vermesidir. Yapılandırmacılık, bilginin çevresel etkenlerden ve ön öğrenmelerden bağımsız olmadığına da vurgu yapmıştır. Bu yaklaşıma göre özellikle değerlerin kazanımında öğrenciler aktif olmalıdır. Değerlerin öğretiminde bu yaklaşıma uygun olarak değer açıklama ve analizi gibi yaklaşımlar, tasarılarda kendini hissettirse de uygulamada öğretmenlerin bunu nasıl yapacakları ya da öğrencileri nasıl aktif hale getireceklerine ilişkin ileri sürülen öneriler yeterince açık değildir. Bunun için de değerler eğitimi etkinlik tasarılarının geliştirilmesinde sorumlu olan komisyonlarda daha çok öğretim tasarımcısı görev almalıdır ve bunlar, öğretmenlere ve ailelere rehberlik yapmalıdır.

Telkine dayalı etkinlikler yerine değerlerin açıklanması, muhakeme ve analizi şeklindeki yaklaşımlar yapılandırmacılığa daha uygun düşmektedir. Ancak değerlerin gerçekleştirilmesinde hangi yaklaşımlar esas alınırsa alınsın öğrencilerin dikkatini ilgili değerlere çekecek, değer hakkında düşünmesini sağlayacak, kendi değerlerini açığa çıkaracak zengin öğrenme-öğretme etkinliklerine ihtiyaç vardır. 


\section{KAYNAKÇA}

Antalya Valiliği İl Millî Eğitim Müdürlüğü (2011). Değerler Eğitimi (Okulöncesi). Antalya Valiliği İl Millî Eğitim Müdürlüğü Yayınları. Antalya.

Antalya Valiliği İl Millî Eğitim Müdürlüğü (2011). Değerler Eğitimi (İlköğretim). Antalya Valiliği İl Millî Eğitim Müdürlüğü Yayınları. Antalya.

Antalya Valiliği İl Millî Eğitim Müdürlüğü (2011). Değerler Eğitimi (Ortaöğretim). Antalya Valiliği İl Millî Eğitim Müdürlüğü Yayınları. Antalya.

Akbaş, O. (2008). "Değer Eğitimi Akımlarına Genel Bir Bakış”. Değerler Eğitimi Dergisi, 6 (16), 9-27.

Aydın, M. (2003). "Gençliğin Değer Algısı”. Değerler Eğitimi Dergisi, 1 (3), 121-144.

Aydın, M. Z. (2010). “Okulda Çalışan Herkesin Görevi Olarak Değerler Eğitimi”. www.mehmetzekiaydin.com (18.11.2011).

Çağlayan, A. (2005). Ahlak Pusulası: Ahlak ve Değerler Eğitimi. İstanbul: Dem Yayınları.

Dilmaç, B. (2002). İnsanca Değerler Eğitimi. Ankara: Nobel Yayınları.

Dilmaç, B., et alii (2008). “Öğretmen Adaylarının Değer Algılarının Farklı Değişkenler Açısından İncelenmesi”. Değerler Eğitimi Dergisi, 6 (16), 69-91.

Doğan, İ. (2011). Eğitim Sosyolojisi. Ankara: Nobel Yayınları.

Erden, M. (1998). Ĕgitimde Program Değerlendirme. Ankara: Anı Yayıncılık.

Ertürk, S. (1993). Eğitimde Program Geliştirme. Ankara: Meteksan Yayınları.

Gelen, İ., et alii (2010). "İlköğretim 5. Sınıf Öğrencilerinin Sosyo Ekonomik Düzeyleri ile Değerleri Arasındaki İlişkinin Belirlenmesi”. Mustafa Kemal Üniversitesi Sosyal Bilimler Enstitüsü Dergisi, 7 (1), 237-246.

Güngör, E. (1993). Değerler Psikolojisi. Hollanda Türk Akademisyenler Birliği Yayınları: 8.

Köseoğu, F., et alii (2002). "Yapılandırmacı Öğrenme Teorisine Dayanan Etkili Bir Öğretim YöntemiTahmin Et - Gözle - Açıkla; Buz ile Su Kaynatılabilir mi?”. V. Ulusal Fen Bilimleri ve Matematik Eğitimi Kongresi (16-18 Eylül 2002). Ankara.

MEB (2012). Millî Eğitim Temel Kanunu. http://mevzuat.meb.gov.tr/html/88.html. (18.03.2012).

Özdemir, S. M. (2009). “Eğitimde Program Değerlendirme ve Türkiye’de Eğitim programlarını Değerlendirme Çalışmalarının İncelenmesi”. Yüzüncü Yıl Üniversitesi Eğitim Fakültesi Dergisi, 6 (2), 126149.

Özelsel, E. (2003). “Sosyolojik Bir Olgu Olarak Değer”. Değerler Eğitimi Dergisi, 1 (3), 217-239.

Şimşek, N. (2004). "Yapılandırmacı Öğrenme ve Öğretime Eleştirel Bir Yaklaşım”. Eğitim Bilimleri ve Uygulama Dergisi, 3 (5), 115-139.

Turan, S., \& Aktan, D. (2008). “Okul Hayatında Var Olan ve Olması Düşünülen Sosyal Değerler”. Türk Eğitim Bilimleri Dergisi, 6 (2), 227-259.

Yurdakul, B. (2005). “Yapılandırmacılık”. Ed. Ö. Demirel, Eğitimde Yeni Yönelimler. Ankara: Pegem Yayıncilık.

Yüksel, S. (2004). Örtük Program Eğitimde Saklı Uygulamalar. Ankara: Nobel Yayınları. 